\title{
SISTEM PENDUKUNG KEPUTUSAN PEMBERIAN REWARD DAN PUNISHMENT KARYAWAN BANK BRI MENGGUNAKAN METODE ADDITIVE RATIO ASSESSMENT (ARAS)
}

\author{
Rosmini $\left(^{1)}\right.$, Darmawati $\left(^{2)}\right.$, dan Muhammad Fadlan $\circledast^{3)}$ \\ 1,2,3Sistem Informasi, STMIK PPKIA Tarakanita Rahmawati \\ 1,2,3 Jl. Yos Sudarso No.8, Tarakan Kalimatan Utara, 77112 \\ E-mail : rosmini@ppkia.ac.id ${ }^{1)}$,darma8790@gmail.com ${ }^{2}$, fadlan@ppkia.ac.id ${ }^{3)}$
}

\begin{abstract}
ABSTRAK
Kualitas pelayanan sumber daya manusia diperlukan untuk menjaga dan meningkat kualitas pelayanan perusahaan dan untuk memacu semangat kerja karyawan, perusahaan harus memenuhi beberapa kriteria melalui penerapan konsep dan teknik manajemen sumber daya manusia yang tepat, salah satunya melalui pemberian reward dan punishment. Reward dan Punishment sangat berpengaruh dalam meningkatkan kinerja karyawan dengan adanya penelitian kinerja untuk pemberian reward dan punishment akan membuat seseorang karyawan lebih disiplin terhadap waktu serta pertanggung jawab dengan tugas yang diberikan oleh perusahaan. Bank BRI Tarakan adalah salah satu Cabang Bank BRI yang ada di Indonesia, Bank BRI Tarakan setiap triwulan memberikan reward dan punishment kepada karyawan Front liner dan Back Office dalam memberikan kontribusi. Saat ini dalam menentukan keputusan pemberian reward dan punishment masih menggunakan Microsoft office excel dan masih membutuhkan waktu yang lama dalam proses penilaian. Penelitian ini menggunakan metode additive ratio assessment (ARAS) untuk ranking atau pengambilan keputusan karyawan yang mendapat reward dan mendapatkan punishment. Data yang digunakan sebanyak data 50 karyawan dengan 4 kriteria presensi bobot 20\%, cross selling $40 \%$, produk knowledge $10 \%$ stand layanan $30 \%$. Hasil dari perhitungan menggunakan metode additive ratio assessment (ARAS) yaitu terdapat 3 karyawan yang akan mendapat reward berdasarkan 3 nilai tertinggi dan 3 karyawan yang mendapat punishment dari 3 nilai terendah selain itu tidak mendapatkan reward dan punishment.
\end{abstract}

Kata Kunci: Reward, Punishment, SPK, ARAS, Kualitas Pelayanan

\section{PENDAHULUAN}

Perkembangan teknologi dunia bisnis yang semakin meningkat mendorong semakin tinggi pula tingkat persaingan dalam bidang usaha, tidak terkecuali dalam sektor jasa. Seiring dengan hal tersebut, maka perusahaan dituntut untuk mencapai penjualan produk sesuai dengan target yang diharapkan dengan melakukan peningkatan kualitas pelayanan sumber daya manusia. Kualitas pelayanan sumber daya manusia diperuntukkan untuk menjaga dan meningkat kualitas pelayanan perusahaan untuk memacu semangat kerja karyawan, perusahaan harus memenuhi beberapa kriteria melalui penerapan konsep dan teknik manajemen sumber daya manusia yang tepat, salah satunya melalui pemberian reward dan punishment. (Pramesti, dkk 2019) (Ramadanita, dkk 2021)

Reward dan Punishment sangat berpengaruh dalam meningkatkan kinerja karyawan, dengan adanya penelitian kinerja untuk pemberian reward dan punishment akan membuat seseorang karyawan lebih disiplin terhadap waktu serta pertanggung jawab dengan tugas yang diberikan oleh perusahaan (Kusuma, dkk 2018).

Bank BRI Tarakan adalah salah satu Cabang Bank BRI yang ada di Indonesia, dimana terdiri dari 1
BRI Kantor Cabang, 1 BRI Kantor Cabang Pembantu disebut juga KCP, 1 Kantor Kas, 5 BRI Unit dan 3 Kantor Teras. Dimana semua dibawah supervisi BRI Kantor Cabang Tarakan. Untuk BRI Kantor Cabang Pembantu, 1 BRI Unit serta 1 Kantor Teras berada di Kabupaten Malinau. Dengan ini Bank BRI Cabang Tarakan setiap triwulan memberikan reward dan punishment kepada karyawan Front liner dan Back Office dalam memberikan kontribusi. Saat ini dalam menentukan keputusan pemberian reward masih menggunakan excel dan masih membutuhkan waktu yang lama dalam proses penilaian. Penilaian pemberian reward dan punishment tersebut masih menggunakan excel sehingga sering terdapat kesalahan dalam penentuan siapa karyawan yang pantas memperoleh reward dan karyawan yang mendapatkan punishment. Reward karyawan berupa uang penghargaan dan punishment karyawan kontrak berupa surat peringatan tidak diperpanjang kontraknya.

Penelitian ini mengacu pada beberapa penelitian sebelumnya. Penelitian pertama yaitu (Dawis, 2020) Sistem Pendukung Keputusan Pemberian Reward Pegawai Menggunakan Metode TOPSIS. Penelitian ini bertujuan untuk membuat sistem pemberian reward pegawai pada RS. PKU Muhammadiyah berdasarkan 
kriteria diantarnya masa kerja, beban dan risiko kerja, keikutsertaan pegawai dalam kegiatan yang diadakan pihak RS tersebut. Penelitian Kedua yaitu (Tri Susilo, dkk 2016) Sistem Pendukung Keputusan Pemberian Reward kepada Karyawan Bandar Udara Silampari Lubuklinggau Menggunakan Metode Composite Performance Index (CPI). Penelitian ini bertujuan untuk memberikan penghargaan kepada karyawan guna meningkatkan semangat, motivasi dan profesionalisme berdasarkan kriteria yang ada yaitu komunikator, perilaku, kerapian, absensi, dan tanggung jawab. Penelitian ketiga yaitu (Pungkasanti, dkk 2018) Pendukung Keputusan Pemberian Reward Dosen dengan Menggunakan Weighted Product (WP). Penelitian ini bertujuan untuk meningkatkan kualitas kinerja dosen dan penerapan sistem penghargaan reward dosen berdasarkan indikator yaitu melaksanakan pendidikan dan pengajaran, melaksanakan penelitian, melaksanakan pengabdian kepada masyarakat dan unsur penunjang dan tugas pokok dosen. Penelitian keempat yaitu (Mandala, dkk 2020) Data Mining Pemberian Reward pada Karyawan UPI Convention Group Menggunakan Nearest Neighbor. Penelitian ini bertujuan untuk menghasilkan sebuah sistem yang dapat membantu manajemen UPI Convention Group dalam mengambil keputusan terhadap karyawan yang berhak menerima reward berdasarkan atribut yaitu kehadiran dan absensi, komunikasi interpersonal, sikap dan perilaku, rajin dan tanggung jawab, memiliki insiatif kualitas karyawan dan kerapian berpakaian. Penelitian kelima yaitu (Aziz, 2021) Sistem Penunjang Keputusan Penentuan Reward Bagi Mitra Terbaik Menggunakan Simple Additive Weighting (SAW). Penelitian ini bertujuan untuk membuat sistem pendukung keputusan pemberian reward bagi mitra terbaik karena selama ini proses penilaiannya masih berdasarkan pendapat manajer sehingga kurang efektif untuk menyelesaikan permasalahan tersebut. Adapun kriteria yang digunakan rekonsiliasi data, atribut, absensi dan kinerja. Berdasarkan pendahuluan diatas penelitian yang terdahulu tersebut hanya menerapkan SPK di bidang kepegawaian untuk kasus pemberian reward saja dan belum untuk pemberian punishment atau sanksi.

Pada penelitian ini bertujuan untuk menghasilkan suatu sistem yang dapat membantu atau memudahkan dalam pengambilan keputusan pemberian reward dan punishment kepada karyawan Bank BRI, sistem ini sering disebut sebagai sistem pendukung keputusan (SPK) atau Decision Support System (DSS). Sistem Pendukung Keputusan (SPK) merupakan aplikasi interaktif berbasis komputer yang mengombinasikan data dan model matematis untuk membantu proses pengambilan keputusan dalam menangani suatu masalah (Rifqo, dkk 2019). Sistem pendukung keputusan bermaksud untuk menyatukan kemampuan komputer dalam pelayanan interaktif terhadap penggunanya dengan adanya proses pengolahan atau pemanipulasi data yang memanfaatkan model atau aturan yang tidak terstruktur sehingga menghasilkan alternatif keputusan yang situasional (Tri Susilo, dkk 2016). Ada banyak metode yang dapat diterapkan pada SPK atau DSS, salah satunya adalah metode Additive Ratio Assessment (ARAS). Maka pada penelitian ini menggunakan metode ARAS untuk ranking atau pengambilan keputusan karyawan yang mendapat reward dan mendapatkan punishment. Metode ARAS merupakan salah satu metode pengambilan keputusan multi kriteria berdasarkan pada konsep ranking menggunakan utility degree yaitu dengan membandingkan nilai indeks keseluruhan setiap alternatif optimal (Sari \& Purba, 2019; Sitompul \& Hasibuan, 2018).

\section{RUANG LINGKUP}

Dalam penelitian ini permasalahan mencakup:

1. Karyawan yang diberikan reward dan punishment adalah karyawan pekerja tetap dan kontrak dalam hal ini pekerja Front liner dan Back Office. Jumlah data yang digunakan sebanyak 50 karyawan.

2. Kriteria yang digunakan dalam menentukan penerimaan reward dan punishment adalah resensi kehadiran (presensi dan ketepatan waktu), cross selling (e-Banking, investasi, simpanan dan kartu kredit), produk knowledge (lisan dan essay) dan standar layanan (penampilan pribadi, sikap, ramah, terampil dan keandalan)

3. Hasil ranking pemberian reward adalah untuk pekerja yang memperoleh nilai tertinggi 1-3, sedangkan pekerja yang memperoleh nilai terendah 1-3 akan diberikan Punishment

\section{BAHAN DAN METODE}

Pada Bab ini menjelaskan bahan/teori yang digunakan dalam penelitian yang melingkupi formula dalam penyelesaian kasus.

\subsection{Sistem Pendukung Keputusan}

Sistem Pendukung Keputusan (SPK) adalah sistem informasi, pemodelan dan pemanipulasi data. Sistem Pendukung Keputusan (SPK) biasanya dibangun untuk mendukung solusi atas suatu masalah atau untuk suatu peluang. Aplikasi Sistem Pendukung Keputusan (SPK) digunakan dalam pengambilan keputusan (Kusrini, 2007). Aplikasi Sistem Pendukung Keputusan (SPK) menggunakan CBIS (Computer Based Information systems) yang fleksibel, interaktif, dan dapat diadaptasi, yang dikembangkan untuk mendukung solusi atas masalah manajemen spesifik yang tidak terstruktur (Lia C. L. \& Hasibuan, 2018)

\subsection{Additive Ratio Assessment}

Metode additive ratio assessment (ARAS). Menurut Stanujkic dan Jovanovic, metode ARAS dikembangkan oleh Zavadskas dan Turskis pada tahun 2010. Metode ARAS merupakan salah satu metode pengambilan keputusan multi kriteria berdasarkan pada konsep ranking menggunakan utility degree yaitu dengan membandingkan nilai indeks keseluruhan setiap 
alternatif optimal (Mesran, dkk 2019) (Addenan, dkk 2021) (Sahir, S. H. \& Panjaitan, 2020) (Sahir, S. H., dkk 2019).

Langkah-langkah perhitungan dengan metode ARAS, sebagai berikut (Hasmi dkk., 2018) (Adali \& Isik, 2016):

1. Pembentukan Decision Making Matriks seperti rumus persamaan (1).

2.

$$
X=\left[\begin{array}{ccccc}
x_{01} & \cdots & x_{0 j} & \cdots & x_{0 n} \\
\vdots & \ddots & \vdots & \ddots & \vdots \\
x_{i 1} & \cdots & x_{i j} & \cdots & x_{i n} \\
\vdots & \ddots & \vdots & \ddots & \vdots \\
x_{n 1} & \cdots & x_{m j} & \cdots & x_{m n}
\end{array}\right] i=\overline{0, m} ; j=\overline{1, n}
$$

keterangan :

$\mathrm{m}=$ Jumlah Alternatif

$\mathrm{n}=$ Jumlah Kriteria

$\mathrm{xij}=$ Nilai performa dari alternative $\mathrm{i}$ terhadap kriteria $\mathrm{j}$

$\mathrm{x} 0 \mathrm{j}=$ nilai optimum dari kriteria

3. Pernormalisasian decision making matriks untuk semua kriteria, seperti rumus persamaan (2).

$$
\bar{X}=\left[\begin{array}{ccccc}
\bar{x}_{01} & \cdots & \bar{x}_{0 j} & \cdots & \bar{x}_{0 n} \\
\vdots & \ddots & \vdots & \ddots & \vdots \\
\bar{x}_{i 1} & \cdots & \bar{x}_{i j} & \cdots & \bar{x}_{i n} \\
\vdots & \ddots & \vdots & \ddots & \vdots \\
\bar{x}_{n 1} & \cdots & \bar{x}_{m j} & \cdots & \bar{x}_{m n}
\end{array}\right] i=\overline{0, m} ; j=\overline{1, n}
$$

Jika pada kriteria yang diusulkan bernilai maksimum maka normalisasi nya, seperti rumus persamaan (3).

$$
\bar{x}_{i j}=\frac{x_{i j}}{\Sigma_{1}^{m}=0 x_{i j}}
$$

Jika pada kriteria yang diusulkan bernilai minimum, maka proses normalisasi nya ada 2 tahap, seperti rumus persamaan (4).

$$
x_{i j}=\frac{1}{x_{i j}} ; \bar{x}_{i j}=\frac{x_{i j}}{\Sigma_{1}^{m}=0 x_{i j}}
$$

4. Menentukan bobot matriks yang sudah dinorrmalisasikan pada tahap 2, seperti rumus persamaan (5).

5.

$$
\sum_{j=1}^{n} W_{j}=1
$$

6. Menentukan nilai dari fungsi optimum, seperti rumus persamaan (6).

$$
S_{i}=\sum_{j=1}^{n} x_{i j} ; i=\overline{o, m},
$$

7. Menentukan tingkatan peringkat, seperti rumus persamaan (7).

$$
K_{i}=\frac{s i}{s o} ; i=\overline{o, m}
$$

\subsection{Metode Penelitian}

Berikut ini metode penelitian yang dilakukan dalam beberapa tahap yang dapat dilihat pada gambar 1 .

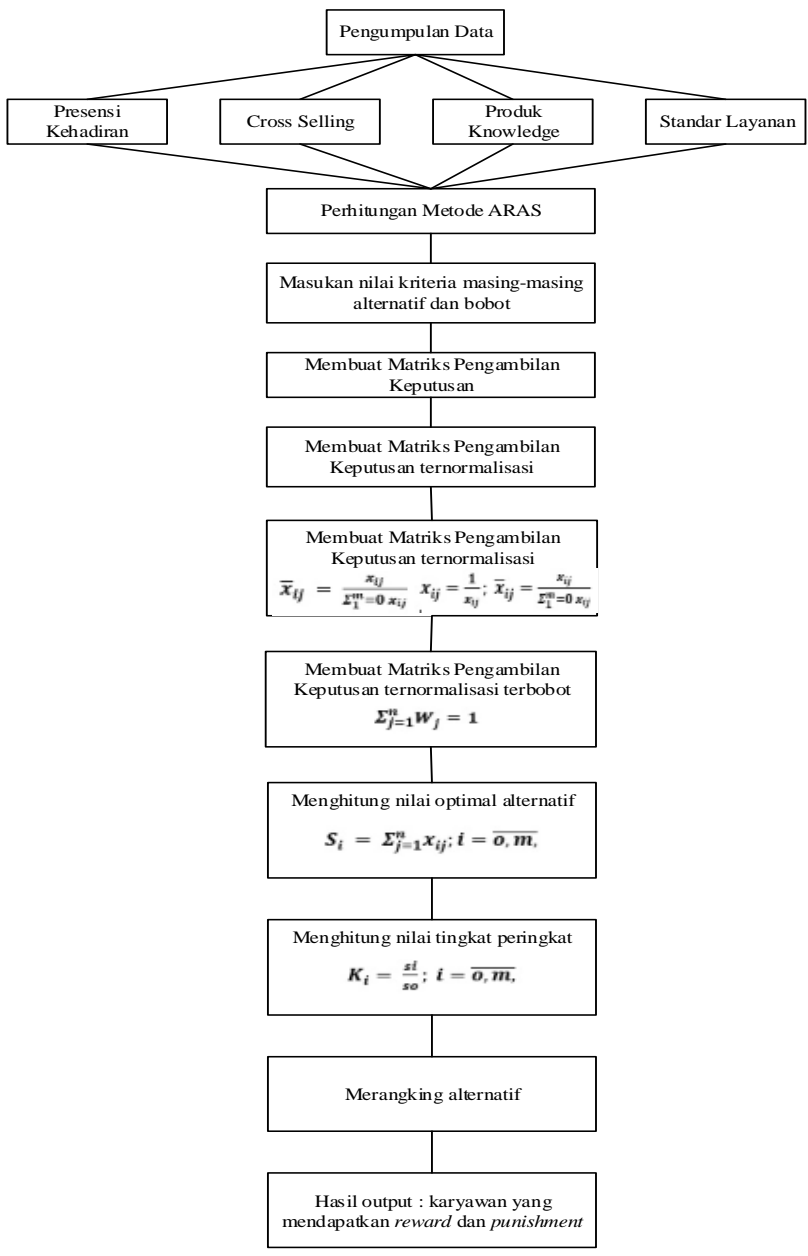

Gambar 1. Metode Penelitian

Metode penelitian pada gambar 1 merupakan tahapan dari pengumpulan data, penentuan kriteria, nilainilai dari kriteria, bobot dari masing-masing kriteria dan perhitungan metode ARAS (Simarmata dkk 2019).

\section{PEMBAHASAN}

Peneliti menerapkan metode ARAS dalam penelitian ini menggunakan 4 kriteria, 13 sub kriteria dan 50 data karyawan.

\subsection{Data Kriteria dan Sub kriteria}

Tabel 1 adalah tabel yang berisi 4 kriteria dan $13 \mathrm{sub}$ kriteria dapat dilihat pada tabel 1. 
Tabel 1. Kriteria dan Sub kriteria

\begin{tabular}{|l|l|l|l|}
\hline Kriteria & \multicolumn{1}{|c|}{ Keterangan } & Sub kriteria & \multicolumn{1}{|c|}{ Keterangan } \\
\hline K1 & $\begin{array}{l}\text { Presensi } \\
\text { Kehadiran }\end{array}$ & K1.1, K.1.2 & $\begin{array}{l}\text { Presensi, } \\
\text { Ketepatan } \\
\text { Waktu }\end{array}$ \\
\hline K2 & Cross Selling & $\begin{array}{l}\text { K2.1, K2.2, } \\
\text { K.2.3, K2.4 }\end{array}$ & $\begin{array}{l}\text { e-Banking, } \\
\text { Investasi, } \\
\text { Simpanan, Kartu } \\
\text { Kredit }\end{array}$ \\
& & & Lisan, Essay \\
\hline K3 & Produk & K3.1, K3.2 & K4.1, K4.2, \\
& Knowledge & $\begin{array}{l}\text { Grooming, } \\
\text { Sikap, Ramah, } \\
\text { Terampil, } \\
\text { Keandalan }\end{array}$ \\
& Standar Layanan & K4.5 & \\
& & &
\end{tabular}

Langkah berikutnya adalah menentukan kecocokan alternatif pada setiap kriteria. Tabel Rating Kecocokan Alternatif dan kriteria K1, K2 dapat dilihat pada tabel 2.

Tabel 2. Rating Kecocokan Alternatif

\begin{tabular}{|c|c|c|c|c|c|c|}
\hline \multirow{2}{*}{ Alternatif } & \multicolumn{6}{|c|}{ Kriteria } \\
\cline { 2 - 7 } & \multicolumn{2}{|c|}{ K1 } & \multicolumn{4}{|c|}{ K2 } \\
\cline { 2 - 7 } & K1.1 & K2.2 & K2.1 & K2.2 & K2.3 & K2.4 \\
\hline A1 & 75 & 77 & 80 & 90 & 80 & 50 \\
\hline A2 & 50 & 55 & 60 & 80 & 79 & 88 \\
\hline A3 & 87 & 100 & 78 & 77 & 88 & 50 \\
\hline A4 & 100 & 77 & 80 & 90 & 88 & 50 \\
\hline A5 & 97 & 55 & 60 & 80 & 87 & 88 \\
\hline A6 & 98 & 100 & 78 & 77 & 86 & 50 \\
\hline A7 & 100 & 77 & 80 & 90 & 85 & 50 \\
\hline A8 & 60 & 55 & 60 & 80 & 84 & 88 \\
\hline A9 & 88 & 100 & 78 & 77 & 90 & 50 \\
\hline A10 & 70 & 77 & 80 & 90 & 100 & 50 \\
\hline$\ldots$. & $\ldots$. & $\ldots$. & $\ldots$. & $\ldots$. & $\ldots$. & $\ldots$. \\
\hline A50 & 88 & 55 & 60 & 80 & 55 & 88 \\
\hline
\end{tabular}

Tabel lanjutan rating kecocokan alternatif dan kriteria K3, K4 dapat dilihat pada tabel 3.

Tabel 3. Rating Kecocokan Alternatif Lanjutan

\begin{tabular}{|c|c|c|c|c|c|c|c|}
\hline \multirow{2}{*}{ Alternatif } & \multicolumn{6}{|c|}{ Kriteria } \\
\cline { 2 - 8 } & \multicolumn{2}{|c|}{ K3 } & \multicolumn{5}{c|}{ K4 } \\
\cline { 2 - 8 } & $\begin{array}{c}\text { K3. } \\
\mathbf{1}\end{array}$ & $\begin{array}{c}\text { K3. } \\
\mathbf{2}\end{array}$ & $\begin{array}{c}\text { K4. } \\
\mathbf{1}\end{array}$ & $\begin{array}{c}\text { K4. } \\
\mathbf{2}\end{array}$ & $\begin{array}{c}\text { K4. } \\
\mathbf{3}\end{array}$ & $\begin{array}{c}\text { K4. } \\
\mathbf{4}\end{array}$ & $\begin{array}{c}\text { K4. } \\
\mathbf{5}\end{array}$ \\
\hline A1 & 88 & 65 & 85 & 77 & 55 & 65 & 66 \\
\hline A2 & 98 & 84 & 65 & 76 & 88 & 93 & 87 \\
\hline A3 & 88 & 98 & 100 & 65 & 55 & 55 & 88 \\
\hline A4 & 88 & 65 & 85 & 77 & 55 & 65 & 66 \\
\hline A5 & 98 & 84 & 65 & 76 & 88 & 93 & 87 \\
\hline A6 & 88 & 98 & 100 & 65 & 55 & 55 & 88 \\
\hline A7 & 88 & 65 & 85 & 77 & 55 & 65 & 66 \\
\hline A8 & 98 & 84 & 65 & 76 & 88 & 93 & 87 \\
\hline A9 & 65 & 98 & 100 & 65 & 55 & 55 & 88 \\
\hline A10 & 77 & 65 & 85 & 77 & 55 & 65 & 66 \\
\hline$\ldots$. & $\ldots$ & $\ldots$ & $\ldots$ & $\ldots$. & $\ldots$. & $\ldots$. & $\ldots$ \\
\hline A50 & 98 & 84 & 65 & 76 & 88 & 93 & 87 \\
\hline
\end{tabular}

Tahap berikutnya menentukan bobot kepentingan dari setiap kriteria. Adapun bobot kriteria yang telah ditentukan oleh pihak Bank BRI dari 4 kriteria yang telah ditentukan semua berjenis benefit dapat dilihat pada tabel 4.

Tabel 4. Bobot Kriteria

\begin{tabular}{|c|c|c|}
\hline Kriteria & Jenis & $\begin{array}{c}\text { Nilai Bobot } \\
\text { Kriteria }\end{array}$ \\
\hline K1 & Benefit & 0.2 \\
\hline K2 & Benefit & 0.4 \\
\hline K3 & Benefit & 0.1 \\
\hline K4 & Benefit & 0.3 \\
\hline
\end{tabular}

Setelah alternatif, kriteria dan telah dibobotkan sehingga mendapatkan matriks keputusan, maka dilakukan perhitungan menggunakan metode ARAS. Pembentukan decision making matriks keputusan menggunakan persamaan (1) dapat dilihat pada tabel 5.

Tabel 5. Matriks Keputusan

\begin{tabular}{|c|c|c|c|c|c|c|}
\hline \multirow{2}{*}{ Alternatif } & \multicolumn{5}{|c|}{ Kriteria } \\
\cline { 2 - 7 } & \multicolumn{2}{|c|}{ K1 } & \multicolumn{4}{c|}{ K2 } \\
\cline { 2 - 7 } & K1.1 & K2.2 & K2.1 & K2.2 & K2.3 & K2.4 \\
\hline A0 & 100 & 100 & 80 & 90 & 100 & 88 \\
\hline A1 & 75 & 77 & 80 & 90 & 80 & 50 \\
\hline A2 & 50 & 55 & 60 & 80 & 79 & 88 \\
\hline A3 & 87 & 100 & 78 & 77 & 88 & 50 \\
\hline A4 & 100 & 77 & 80 & 90 & 88 & 50 \\
\hline A5 & 97 & 55 & 60 & 80 & 87 & 88 \\
\hline A6 & 98 & 100 & 78 & 77 & 86 & 50 \\
\hline A7 & 100 & 77 & 80 & 90 & 85 & 50 \\
\hline A8 & 60 & 55 & 60 & 80 & 84 & 88 \\
\hline A9 & 88 & 100 & 78 & 77 & 90 & 50 \\
\hline A10 & 70 & 77 & 80 & 90 & 100 & 50 \\
\hline$\ldots .$. & $\ldots$. & $\ldots$. & $\ldots$. & $\ldots$. & $\ldots$. & $\ldots$. \\
\hline A50 & 88 & 55 & 60 & 80 & 55 & 88 \\
\hline Criteria & \multirow{2}{*}{ Max } & \multirow{2}{*}{ Max } & \multirow{2}{*}{ Max } & \multirow{2}{*}{ Max } & Max & Max \\
\hline Type & & & & & & \\
\hline
\end{tabular}

$$
x_{i j}=\left[\begin{array}{cccccc}
100 & 100 & 80 & 90 & 100 & 88 \\
75 & 77 & 80 & 90 & 90 & 50 \\
50 & 55 & 60 & 80 & 79 & 88 \\
87 & 100 & 78 & 77 & 88 & 50 \\
100 & 77 & 80 & 90 & 88 & 50 \\
97 & 55 & 60 & 80 & 87 & 88 \\
98 & 100 & 78 & 77 & 86 & 50 \\
100 & 77 & 80 & 90 & 85 & 50 \\
60 & 55 & 60 & 80 & 84 & 88 \\
88 & 100 & 78 & 77 & 90 & 50 \\
70 & 77 & 80 & 90 & 100 & 50 \\
\ldots & \ldots & \ldots & \ldots & \ldots & \ldots \\
88 & 55 & 60 & 80 & 55 & 88
\end{array}\right]
$$

Untuk nilai alternatif A0 didapatkan dari nilai maximal dari masing- masing kriteria. Pada Matriks di atas dijumlahkan ke bawah sehingga mendapatkan hasil penjumlahan masing-masing kriteria sebagai berikut: :

\section{$\left[\begin{array}{llllll}4079 & 3944 & 3708 & 4212 & 3961 & 3234\end{array}\right]$}

Tabel lanjutan decision making matriks kriteria K3, K4 dapat dilihat pada tabel 6. 
Tabel 6. Matriks Keputusan Lanjutan

\begin{tabular}{|c|c|c|c|c|c|c|c|}
\hline \multirow{3}{*}{ Alternatif } & \multicolumn{7}{|c|}{ Kriteria } \\
\hline & \multicolumn{2}{|c|}{ K3 } & \multicolumn{5}{|c|}{ K4 } \\
\hline & $\begin{array}{c}\text { K3. } \\
1\end{array}$ & $\begin{array}{c}\text { K3. } \\
2\end{array}$ & $\begin{array}{c}\text { K4. } \\
1\end{array}$ & $\begin{array}{c}\text { K4. } \\
2\end{array}$ & $\begin{array}{c}\text { K4. } \\
3\end{array}$ & $\begin{array}{c}\text { K4. } \\
4\end{array}$ & $\begin{array}{c}\text { K4. } \\
5\end{array}$ \\
\hline A0 & 100 & 98 & 100 & 77 & 88 & 93 & 88 \\
\hline A1 & 88 & 65 & 85 & 77 & 55 & 65 & 66 \\
\hline A2 & 98 & 84 & 65 & 76 & 88 & 93 & 87 \\
\hline A3 & 88 & 98 & 100 & 65 & 55 & 55 & 88 \\
\hline A4 & 88 & 65 & 85 & 77 & 55 & 65 & 66 \\
\hline A5 & 98 & 84 & 65 & 76 & 88 & 93 & 87 \\
\hline A6 & 88 & 98 & 100 & 65 & 55 & 55 & 88 \\
\hline A7 & 88 & 65 & 85 & 77 & 55 & 65 & 66 \\
\hline \multirow{3}{*}{ Alternatif } & \multicolumn{7}{|c|}{ Kriteria } \\
\hline & \multicolumn{2}{|c|}{ K3 } & \multicolumn{5}{|c|}{ K4 } \\
\hline & $\begin{array}{c}\mathrm{K} 3 . \\
1\end{array}$ & $\begin{array}{c}\text { K3. } \\
2\end{array}$ & $\begin{array}{c}\text { K4. } \\
1\end{array}$ & $\begin{array}{c}\text { K4. } \\
2\end{array}$ & $\begin{array}{c}\text { K4. } \\
3\end{array}$ & $\begin{array}{c}\text { K4. } \\
4\end{array}$ & $\begin{array}{c}\text { K4. } \\
5\end{array}$ \\
\hline A8 & 98 & 84 & 65 & 76 & 88 & 93 & 87 \\
\hline A9 & 65 & 98 & 100 & 65 & 55 & 55 & 88 \\
\hline A10 & 77 & 65 & 85 & 77 & 55 & 65 & 66 \\
\hline .... & $\ldots$ & $\ldots$ & $\ldots$ & $\ldots$. & $\ldots$ & $\ldots$ & $\ldots$ \\
\hline A50 & 98 & 84 & 65 & 76 & 88 & 93 & 87 \\
\hline $\begin{array}{l}\text { Criteria } \\
\text { Type }\end{array}$ & $\operatorname{Max}$ & $\operatorname{Max}$ & $\operatorname{Max}$ & Max & Max & $\operatorname{Max}$ & $\operatorname{Max}$ \\
\hline
\end{tabular}

Kriteria tipe max apabila jenis kriteria adalah benefit dan bernilai min apabila jenis kriteria cost. Tahap selanjutnya adalah merumuskan matriks keputusan dengan kriteria K1, K2 menggunakan persamaan 3, dapat dilihat pada tabel 7 .

Tabel 7. Matriks Keputusan Lanjutan

\begin{tabular}{|c|c|c|c|c|c|c|}
\hline \multirow{2}{*}{ Alternatif } & \multicolumn{6}{|c|}{ Kriteria } \\
\cline { 2 - 7 } & \multicolumn{2}{|c|}{ K1 } & \multicolumn{4}{c|}{ K2 } \\
\cline { 2 - 7 } & K1.1 & K2.2 & K2.1 & K2.2 & K2.3 & K2.4 \\
\hline A0 & 100 & 100 & 80 & 90 & 100 & 88 \\
\hline A1 & 75 & 77 & 80 & 90 & 80 & 50 \\
\hline A2 & 50 & 55 & 60 & 80 & 79 & 88 \\
\hline A3 & 87 & 100 & 78 & 77 & 88 & 50 \\
\hline A4 & 100 & 77 & 80 & 90 & 88 & 50 \\
\hline A5 & 97 & 55 & 60 & 80 & 87 & 88 \\
\hline A6 & 98 & 100 & 78 & 77 & 86 & 50 \\
\hline A7 & 100 & 77 & 80 & 90 & 85 & 50 \\
\hline A8 & 60 & 55 & 60 & 80 & 84 & 88 \\
\hline A9 & 88 & 100 & 78 & 77 & 90 & 50 \\
\hline A10 & 70 & 77 & 80 & 90 & 100 & 50 \\
\hline$\ldots .$. & $\ldots$. & $\ldots$. & $\ldots$. & $\ldots$. & $\ldots$. & $\ldots$. \\
\hline A50 & 88 & 55 & 60 & 80 & 55 & 88 \\
\hline Jumlah & 4079 & 3944 & 3708 & 4212 & 3961 & 3234 \\
\hline
\end{tabular}

Tabel lanjutan merumuskan matriks keputusan dengan kriteria K3, K4 dapat dilihat pada tabel 8.

Tabel 8. Merumuskan Matriks Keputusan Lanjutan

\begin{tabular}{|c|c|c|c|c|c|c|c|}
\hline \multirow{2}{*}{ Alternatif } & \multicolumn{7}{|c|}{ Kriteria } \\
\cline { 2 - 8 } & \multicolumn{2}{|c|}{ K3 } & \multicolumn{5}{c|}{ K4 } \\
\cline { 2 - 8 } & $\begin{array}{c}\text { K3. } \\
\mathbf{1}\end{array}$ & $\begin{array}{c}\text { K3. } \\
\mathbf{2}\end{array}$ & $\begin{array}{c}\text { K4. } \\
\mathbf{1}\end{array}$ & $\begin{array}{c}\text { K4. } \\
\mathbf{2}\end{array}$ & $\begin{array}{c}\text { K4. } \\
\mathbf{3}\end{array}$ & $\begin{array}{c}\text { K4. } \\
\mathbf{4}\end{array}$ & $\begin{array}{c}\text { K4. } \\
\mathbf{5}\end{array}$ \\
\hline A0 & 100 & 98 & 100 & 77 & 88 & 93 & 88 \\
\hline A1 & 88 & 65 & 85 & 77 & 55 & 65 & 66 \\
\hline A2 & 98 & 84 & 65 & 76 & 88 & 93 & 87 \\
\hline A3 & 88 & 98 & 100 & 65 & 55 & 55 & 88 \\
\hline A4 & 88 & 65 & 85 & 77 & 55 & 65 & 66 \\
\hline A5 & 98 & 84 & 65 & 76 & 88 & 93 & 87 \\
\hline A6 & 88 & 98 & 100 & 65 & 55 & 55 & 88 \\
\hline A7 & 88 & 65 & 85 & 77 & 55 & 65 & 66 \\
\hline A8 & 98 & 84 & 65 & 76 & 88 & 93 & 87 \\
\hline A9 & 65 & 98 & 100 & 65 & 55 & 55 & 88 \\
\hline A10 & 77 & 65 & 85 & 77 & 55 & 65 & 66 \\
\hline$\ldots$. & $\ldots$. & $\ldots$. & $\ldots$. & $\ldots$. & $\ldots$. & $\ldots$ & $\ldots$ \\
\hline A50 & 98 & 84 & 65 & 76 & 88 & 93 & 87 \\
\hline Jumlah & 428 & 419 & 425 & 371 & 339 & 365 & 409 \\
& 1 & 9 & 0 & 8 & 9 & 9 & 7 \\
\hline
\end{tabular}

1. Normalisasi Matriks Keputusan

Nomalisasi matriks keputusan untuk semua kriteria menggunakan persamaan (4).

$$
\begin{aligned}
& R_{10}=\frac{100}{4079}=0.025 \\
& R_{11}=\frac{75}{4079}=0.018 \\
& R_{12}=\frac{50}{4079}=0.012 \\
& R_{13}=\frac{87}{4079}=0.021 \\
& R_{14}=\frac{100}{4075}=0.025
\end{aligned}
$$

Perhitungan diatas adalah 5 nilai K1 dibagi dengan total penjumlahan nilai K1. Perhitungan diatas dapat diperoleh matriks keputusan yang telah dinormalisasikan dapat dilihat pada tabel 9 .

Tabel 9. Matriks X*

\begin{tabular}{|c|c|c|c|c|c|}
\hline \multicolumn{7}{|c|}{ K1 } & \multicolumn{3}{c|}{ K2 } \\
\hline K1.1 & K2.2 & K2.1 & K2.2 & K2.3 & K2.4 \\
\hline 0,025 & 0,025 & 0,022 & 0,021 & 0,025 & 0,027 \\
\hline 0,018 & 0,020 & 0,022 & 0,021 & 0,020 & 0,015 \\
\hline 0,012 & 0,014 & 0,016 & 0,019 & 0,020 & 0,027 \\
\hline 0,021 & 0,025 & 0,021 & 0,018 & 0,022 & 0,015 \\
\hline 0,025 & 0,020 & 0,022 & 0,021 & 0,022 & 0,015 \\
\hline 0,024 & 0,014 & 0,016 & 0,019 & 0,022 & 0,027 \\
\hline 0,024 & 0,025 & 0,021 & 0,018 & 0,022 & 0,015 \\
\hline 0,025 & 0,020 & 0,022 & 0,021 & 0,021 & 0,015 \\
\hline 0,015 & 0,014 & 0,016 & 0,019 & 0,021 & 0,027 \\
\hline 0,022 & 0,025 & 0,021 & 0,018 & 0,023 & 0,015 \\
\hline 0,017 & 0,020 & 0,022 & 0,021 & 0,025 & 0,015 \\
\hline$\ldots$. & $\ldots$. & $\ldots .$. & $\ldots$. & $\ldots$. & $\ldots$. \\
\hline 0,022 & 0,014 & 0,016 & 0,019 & 0,014 & 0,027 \\
\hline
\end{tabular}


Tabel lanjutan matriks $\mathrm{x}^{*}$ dengan kriteria $\mathrm{K} 3, \mathrm{~K} 4$ dapat dilihat pada tabel 10 .

Tabel 10. Matriks X* Lanjutan

\begin{tabular}{|c|c|c|c|c|c|c|}
\hline \multicolumn{7}{|c|}{ Kriteria } \\
\hline \multicolumn{2}{|c|}{ K3 } & \multicolumn{5}{c|}{ K4 } \\
\hline K3.1 & K3.2 & K4.1 & K4.2 & K4.3 & K4.4 & K4.5 \\
\hline 0,023 & 0,023 & 0,024 & 0,021 & 0,026 & 0,025 & 0,021 \\
\hline 0,021 & 0,015 & 0,020 & 0,021 & 0,016 & 0,018 & 0,016 \\
\hline 0,023 & 0,020 & 0,015 & 0,020 & 0,026 & 0,025 & 0,021 \\
\hline 0,021 & 0,023 & 0,024 & 0,017 & 0,016 & 0,015 & 0,021 \\
\hline 0,021 & 0,015 & 0,020 & 0,021 & 0,016 & 0,018 & 0,016 \\
\hline 0,023 & 0,020 & 0,015 & 0,020 & 0,026 & 0,025 & 0,021 \\
\hline 0,021 & 0,023 & 0,024 & 0,017 & 0,016 & 0,015 & 0,021 \\
\hline 0,021 & 0,015 & 0,020 & 0,021 & 0,016 & 0,018 & 0,016 \\
\hline 0,023 & 0,020 & 0,015 & 0,020 & 0,026 & 0,025 & 0,021 \\
\hline 0,015 & 0,023 & 0,024 & 0,017 & 0,016 & 0,015 & 0,021 \\
\hline 0,018 & 0,015 & 0,020 & 0,021 & 0,016 & 0,018 & 0,016 \\
\hline$\ldots$. & $\ldots$. & $\ldots$. & $\ldots$. & $\ldots$. & $\ldots$. & $\ldots$. \\
\hline 0,023 & 0,020 & 0,015 & 0,020 & 0,026 & 0,025 & 0,021 \\
\hline
\end{tabular}

2. Perhitungan Bobot Matriks Normalisasi

Penentuan Bobot Matriks menggunakan persamaan (5).

$$
\begin{aligned}
& D_{10}=0.025 * 0.2 \\
& =0.005 \\
& D_{11}=0.018 * 0.2 \\
& =0.004 \\
& D_{12}=0.012 * 0.2 \\
& =0.002 \\
& D_{13}=0.021 * 0.2 \\
& =0.004 \\
& D_{14}=0.025 * 0.2 \\
& =0.005
\end{aligned}
$$

D adalah nilai bobot matriks dari nilai normalisasi * bobot kriteria. Hasil perhitungan diatas dirumuskan dalam matriks dapat dilihat pada tabel 11 .

Tabel 11. Matriks D

\begin{tabular}{|c|c|c|c|c|c|}
\hline \multicolumn{7}{|c|}{ Kriteria } \\
\hline K1 & \multicolumn{3}{c|}{ K2 } \\
\hline K1.1 & K2.2 & K2.1 & K2.2 & K2.3 & K2.4 \\
\hline 0,005 & 0,005 & 0,009 & 0,009 & 0,010 & 0,011 \\
\hline 0,004 & 0,004 & 0,009 & 0,009 & 0,008 & 0,006 \\
\hline 0,002 & 0,003 & 0,006 & 0,008 & 0,008 & 0,011 \\
\hline 0,004 & 0,005 & 0,008 & 0,007 & 0,009 & 0,006 \\
\hline 0,005 & 0,004 & 0,009 & 0,009 & 0,009 & 0,006 \\
\hline 0,005 & 0,003 & 0,006 & 0,008 & 0,009 & 0,011 \\
\hline 0,005 & 0,005 & 0,008 & 0,007 & 0,009 & 0,006 \\
\hline 0,005 & 0,004 & 0,009 & 0,009 & 0,009 & 0,006 \\
\hline 0,003 & 0,003 & 0,006 & 0,008 & 0,008 & 0,011 \\
\hline 0,004 & 0,005 & 0,008 & 0,007 & 0,009 & 0,006 \\
\hline 0,003 & 0,004 & 0,009 & 0,009 & 0,010 & 0,006 \\
\hline$\ldots$. & $\ldots$. & $\ldots .$. & $\ldots$. & $\ldots .$. & $\ldots$ \\
\hline 0,004 & 0,003 & 0,006 & 0,008 & 0,006 & 0,011 \\
\hline
\end{tabular}

Tabel lanjutan matriks D dengan kriteria K3, K4 dapat dilihat pada tabel 12 .
Tabel 12. Matriks D Lanjutan

\begin{tabular}{|c|c|c|c|c|c|c|}
\hline \multicolumn{7}{|c|}{ Kriteria } \\
\hline \multicolumn{2}{|c|}{ K3 } & \multicolumn{5}{c|}{ K4 } \\
\hline K3.1 & $\mathbf{K 3 . 2}$ & $\mathbf{K 4 . 1}$ & $\mathbf{K 4 . 2}$ & $\mathbf{K 4 . 3}$ & $\mathbf{K 4 . 4}$ & K4.5 \\
\hline 0,002 & 0,002 & 0,007 & 0,006 & 0,008 & 0,008 & 0,006 \\
\hline 0,002 & 0,002 & 0,006 & 0,006 & 0,005 & 0,005 & 0,005 \\
\hline 0,002 & 0,002 & 0,005 & 0,006 & 0,008 & 0,008 & 0,006 \\
\hline 0,002 & 0,002 & 0,007 & 0,005 & 0,005 & 0,005 & 0,006 \\
\hline 0,002 & 0,002 & 0,006 & 0,006 & 0,005 & 0,005 & 0,005 \\
\hline 0,002 & 0,002 & 0,005 & 0,006 & 0,008 & 0,008 & 0,006 \\
\hline 0,002 & 0,002 & 0,007 & 0,005 & 0,005 & 0,005 & 0,006 \\
\hline 0,002 & 0,002 & 0,006 & 0,006 & 0,005 & 0,005 & 0,005 \\
\hline 0,002 & 0,002 & 0,005 & 0,006 & 0,008 & 0,008 & 0,006 \\
\hline 0,002 & 0,002 & 0,007 & 0,005 & 0,005 & 0,005 & 0,006 \\
\hline 0,002 & 0,002 & 0,006 & 0,006 & 0,005 & 0,005 & 0,005 \\
\hline$\ldots$. & $\ldots .$. & $\ldots$. & $\ldots$. & $\ldots$. & $\ldots$. & $\ldots$. \\
\hline 0,002 & 0,002 & 0,005 & 0,006 & 0,008 & 0,008 & 0,006 \\
\hline
\end{tabular}

3. Perhitungan Nilai Fungsi Optimalisasi

Nilai fungsi optimalisasi diperoleh dengan cara menjumlahkan nilai kriteria pada setiap alternatif dari hasil perkalian matriks dengan bobot yang telah dilakukan sebelumnya dengan menggunakan persamaan (6).

$\mathrm{S} 1=0.005+0.009+0.009+0.010+0.011+0.002+$ $0.002+0.002+0.007+0.006+0.008+0.008+$ $0.006=0.088$

Hasil perhitungan diatas maka diperoleh nilai $\mathrm{Si}$ dirumuskan pada tabel, dapat dilihat pada tabel 13 .

Tabel 13. Nilai SI

\begin{tabular}{|c|c|}
\hline Alternatif & Si \\
\hline A0 & 0,088 \\
\hline A1 & 0,070 \\
\hline A2 & 0,075 \\
\hline A3 & 0,073 \\
\hline A4 & 0,072 \\
\hline A5 & 0,078 \\
\hline A6 & 0,073 \\
\hline A7 & 0,072 \\
\hline A8 & 0,076 \\
\hline A9 & 0,072 \\
\hline A10 & 0,071 \\
\hline$\ldots$. & $\ldots$ \\
\hline A50 & 0,074 \\
\hline
\end{tabular}

4. Ranking Alternatif

Ranking dilakukan dengan cara membagi nilai alternatif terhadap $0 \quad\left(\mathrm{~A}_{0}\right)$ menggunakan persamaan (7).

$K_{10}=\frac{0.088}{0.088}=1.000$

$K_{11}=\frac{0.070}{0.088}=0.795$ 
$K_{12}=\frac{0.075}{0.088}=0.853$

$K_{13}=\frac{0.073}{0.088}=0.826$

$K_{14}=\frac{0.072}{0.088}=0.818$

Hasil perhitungan diatas maka diperoleh nilai $\mathrm{Ki}$ dirumuskan pada tabel, dapat dilihat pada tabel 14.

Tabel 14. Nilai KI

\begin{tabular}{|c|c|}
\hline Alternatif & Ki \\
\hline A0 & 1,000 \\
\hline A1 & 0,795 \\
\hline A2 & 0,853 \\
\hline A3 & 0,826 \\
\hline A4 & 0,818 \\
\hline A5 & 0,888 \\
\hline A6 & 0,830 \\
\hline A7 & 0,814 \\
\hline A8 & 0,864 \\
\hline$\ldots$. & $\cdots$ \\
\hline A50 & 0,846 \\
\hline
\end{tabular}

Dari hasil ranking diatas dapat disusun alternatif dari nilai tertinggi dapat dilihat pada tabel 15 .

Tabel 15. Ranking Dari Nilai Tertinggi

\begin{tabular}{|c|c|c|c|c|c|}
\hline Ranking & Ki & Alt & Ranking & Ki & Alt \\
\hline 1 & 0,893 & A14 & 26 & 0,818 & A4 \\
\hline 2 & 0,888 & A5 & 27 & 0,814 & A7 \\
\hline 3 & 0,887 & A23 & 28 & 0,814 & A18 \\
\hline 4 & 0,879 & A44 & 29 & 0,812 & A10 \\
\hline 5 & 0,878 & A17 & 30 & 0,809 & A27 \\
\hline 6 & 0,871 & A20 & 31 & 0,809 & A36 \\
\hline 7 & 0,864 & A8 & 32 & 0,808 & A12 \\
\hline 8 & 0,859 & A47 & 33 & 0,806 & A39 \\
\hline 9 & 0,853 & A2 & 34 & 0,804 & A16 \\
\hline 10 & 0,849 & A38 & 35 & 0,799 & A15 \\
\hline 11 & 0,849 & A11 & 36 & 0,799 & A22 \\
\hline 12 & 0,847 & A29 & 37 & 0,795 & A46 \\
\hline 13 & 0,846 & A50 & 38 & 0,795 & A43 \\
\hline 14 & 0,845 & A35 & 39 & 0,795 & A1 \\
\hline 15 & 0,842 & A41 & 40 & 0,794 & A28 \\
\hline 16 & 0,837 & A32 & 41 & 0,794 & A19 \\
\hline 17 & 0,837 & A26 & 42 & 0,786 & A40 \\
\hline 18 & 0,834 & A45 & 43 & 0,786 & A48 \\
\hline 19 & 0,830 & A6 & 44 & 0,784 & A37 \\
\hline 20 & 0,830 & A24 & 45 & 0,781 & A34 \\
\hline 21 & 0,827 & A42 & 46 & 0,778 & A30 \\
\hline 22 & 0,826 & A3 & 47 & 0,773 & A25 \\
\hline 23 & 0,823 & A9 & 48 & 0,773 & A33 \\
\hline 24 & 0,820 & A21 & 49 & 0,772 & A31 \\
\hline 25 & 0,818 & A13 & 50 & 0,759 & A49 \\
\hline & & & & & \\
\hline
\end{tabular}

Berdasarkan hasil perhitungan metode ARAS diperoleh hasil keputusan berupa 3 data karyawan yang mendapatkan reward yang diperoleh dari 3 nilai tertinggi dan 3 karyawan yang mendapatkan punishment yang diperoleh dari 3 nilai terendah dari 50 data yang digunakan dapat dilihat pada tabel 16 .

Tabel 16. Keputusan

\begin{tabular}{|c|c|c|}
\hline Alt & Nilai Ki & Keterangan \\
\hline A14 & 0,893 & Reward \\
\hline A5 & 0,888 & Reward \\
\hline A23 & 0,887 & Reward \\
\hline A33 & 0,773 & Punishment \\
\hline A31 & 0,772 & Punishment \\
\hline A49 & 0,759 & Punishment \\
\hline
\end{tabular}

\section{KESIMPULAN}

Pada penelitian ini menggunakan 50 data karyawan dan 4 kriteria penentuan pemberian reward dan punishment (presensi kehadiran, cross selling, produk knowledge, standar layanan) dan 13 sub kriteria.

Penerapan metode ARAS pada sistem pendukung keputusan pemberian reward dan punishment telah diimplementasikan dengan baik sehingga menghasilkan output yang diinginkan. Pada penelitian ini terdapat 2 output yaitu mendapatkan reward dan mendapatkan punishment.

\section{SARAN}

Penentuan bobot kriteria pada Metode ARAS masih bersifat subjektif sehingga memungkinkan bias pada bobot. Masalah ini dapat di eksplorasi lebih lanjut dengan mengombinasikan atau integrasi metode AHP atau metode Fuzzy. Pada Metode AHP bobotnya berdasarkan pengguna berbentuk deskripsi seperti sangat penting, lebih penting, dan sama penting sedangkan Fuzzy memiliki konsep yang mirip dengan nilai samar nya sehingga peneliti menyarankan untuk mengombinasi metode ARAS dengan metode AHP agar penilaian bobot memiliki dasar perhitungan yang kuat.

\section{DAFTAR PUSTAKA}

Adali, E. A., \& Isik, A. T. 2016. Air conditioner selection problem with COPRAS and ARAS methods. Manas Sosyal Araştırmalar Dergisi, 5(2), 124-138.

Addenan, R., \& Susanti, W. 2021. Penerapan Metode Rank Order Centroid dan Additive Ratio Assessment Pada Aplikasi Rekomendasi Supplier. Edumatic: Jurnal Pendidikan Informatika, 5(1), 31-40.

https://doi.org/10.29408/edumatic.v5i1.3252

Aziz, F. 2021. Sistem Penunjang Keputusan Penentuan Reward Bagi Mitra Terbaik Menggunakan Metode Simple Additive Weighting (SAW) (Studi Kasus : PT. Telkom Akses). Jurnal Fasilkom, 11(2), 9196. https://doi.org/10.37859/jf.v11i2.2715

Dawis, A. M. 2020. Sistem Pendukung Keputusan 
Pemberian Reward Pegawai Menggunakan Metode TOPSIS. Jurnal Ilmiah SINUS, 18(1), 11. https://doi.org/10.30646/sinus.v18i1.429

Hasmi, M. A., Mesran., \& Nadeak, B. 2018. Sistem Pendukung Keputusan Penerimaan Instruktur Fitness Menerapkan Metode Additive Ratio Assessment (Aras)(Studi Kasus: Vizta Gym Medan). KOMIK (Konferensi Nasional Teknologi Informasi Dan Komputer), 2(1).

Kusrini, K. 2007. Aplikasi Sistem Pendukung Keputusan. Yogyakarta: Andi.

Kusuma, M., \& Luturlean, B. S. 2018. Pengaruh Reward dan Punishment Terhadap Kinerja Karyawan Perusahaan Startup Entra Indonesia. Sosiohumanitas, 20(2), 54-63. https://doi.org/10.36555/sosiohumanitas.v20i2.111

Lia C. L., \& Hasibuan, N. A. 2018. Sistem Pendukung Keputusan Pemilihan Team Leader Shift Terbaik Dengan Menggunakan Metode Aras Studi Kasus Pt. Anugrah Busana Indah. Informasi Dan Teknologi Ilmiah (INTI), 13(1), 16-21.

Mandala, E. P. W., \& Ridwan, M.Putri, D. E. 2020. Data Mining Pemberian Reward Pada Karyawan Upi Convention Group Menggunakan Nearest Neighbor. Sebatik, 24(1), 37-44. https://doi.org/10.46984/sebatik.v24i1.881

Mesran., Afriany, J., \& Sahir, S. H. 2019. Efektifitas Penilaian Kinerja Karyawan Dalam Peningkatan Motivasi Kerja Menerapkan Metode Rank Order Centroid (ROC) dan Additive Ratio Assessment (ARAS). Prosiding Seminar Nasional Riset Information Science (SENARIS), 1(September), 813. https://doi.org/10.30645/senaris.v1i0.88

Pramesti, R. A., Sambul, S. A. P., \& Rumawas, W. 2019. Pengaruh Reward Dan Punishment Terhadap Kinerja Karyawan KFC Artha Gading. Jurnal Administrasi Bisnis, $9(1), \quad 57$. https://doi.org/10.35797/jab.9.1.2019.23557.57-63

Pungkasanti, P. T., Handayani, T., \& Indriyawati, H. 2018. Pendukung Keputusan Pemberian Reward Dosen Dengan Menggunakan Weighted Product ( WP ). Jurnal Informatika Upgris (JIU), 4(1).

Ramadanita, D. N., Nugroho, E. S., \& Suyaman, D. J. 2021. Pengaruh Reward dan Punishment Terhadap Kinerja Karyawan PT Glenmore Agung Nusantara. Syntax Literate; Jurnal Ilmiah Indonesia, 6(1), 173-183.

Rifqo, M. H., Prabowo, D. A., \& Dernata, J. 2019. Sistem Pendukung Keputusan untuk Pemberian Reward Kader Terbaik Organisasi Ikatan Mahasiswa Muhammadiyah Kota Bengulu Menggunakan Algoritma Simple Additive Weighting. Journal of Technopreneurship and Information System (JTIS), 2(2), 81-88. https://doi.org/10.36085/jtis.v2i2.372

Sahir, S. H., \& Panjaitan, S. A. 2020. Penerapan Metode Additive Ratio Assessment (ARAS) Untuk Mendukung Penilaian Kinerja Guru Pada SDN
Sentul. Journal of Informatics, Information System, Software Engineering and Applications Penerapan, 8106, 1-13.

Sahir, S. H., \& Panjaitan, S. A. 2019. Analisis Penerapan Metode Additive Ratio Assessment (ARAS) Pada Pemberian Insentif Sales Penjualan Guna Mendukung Keputusan Manajemen. Seminar Nasional Teknologi Komputer \& Sains (SAINTEKS), l(1).

Sari, S. W., \& Purba, B. 2019. Sistem Pendukung Keputusan Pemilihan Ketua Danru Terbaik Menggunakan Metode ARAS. Seminar Nasional Teknologi Komputer \& Sains (SAINTEKS) SAINTEKS 2019, 291-300.

Simarmata, D., Marisa Midyanti, D., \& Hidayati, R. 2019. Implementasi Metode Additive Ratio Assesment (Aras) Untuk Rekomendasi Pasien Kunjungan Sehat Pada Fasilitas Kesehatan Tingkat Pertama Dr Josepb Nugroho H. Coding: Jurnal Komputer Dan Aplikasi, 07(03), 109-119.

Sitompul, T. R., \& Hasibuan, N. A. 2018. Sistem Pendukung Keputusan Seleksi Tenaga Kerja Untuk Security Service Menggunakan Metode Aras. Jurnal Media Informatika Budidarma, 2(1), 1-9. https://doi.org/10.30865/mib.v2i1.812

Tri Susilo, A. A., \& Putri, M. 2016. Sistem Pendukung Keputusan Pemberian Reward Kepada Karyawan Bandar Udara Silampari Lubuklinggau Menggunakan Metode Composite Performance Index(CPI). Jurnal Komputer Terapan, 2(2), 105116. 